\title{
INTERLOCKED INTRAMEDULLARY NAILING OF LONG BONES
}

\author{
*DR. MANSOOR ILYAS, M.S (Ortho) \\ Quetta \\ DR. MOHAMMAD IDRESS, M.S (Surgery) \\ Quetta \\ DR. SIAFUDDIN TAREEN, M.P.H \\ Quetta
}

Article received on:

$18 / 03 / 2006$

Accepted for publication: 22/06/2006

\begin{abstract}
Intramedullary interlocking nailing is the recommended procedure of fixation of long bones fracture. This type of fixation allow the patient to walk independently in few days time, but unlikely there are only few centers in our country which are doing this practice. In Mansoor Orthopedic Hospital and Sandeman Civil Hospital Quetta we started this type of fixation from November 2001 and we have done 15 femoral ( 13 closed and 2 open GII) and 15 tibial (11 closed and 4 open GI \& GII). Interlocking nails up till now. Our early results revealed $0 \%$ infection rate, breakage of nail in one case and bending of one distal locking screw. Inspite this in both cases fracture healed with out any surgical intervention. Patient had nearly full range of movements of both knee \& hip joint. We recommend close Intramedullary in interlocking nailing is an excellent technique to treat long bone fracture regarding good healing minimum complication shorter hospital stay and early functional rehabilitation.
\end{abstract}

\section{INTRODUCTION}

Early mobilization of patients is an important factor in treating the fractures of long bones of limbs if internal fixation is indicated the ideal treatment for the fractures of the shaft of femur and tibia is Intramedullary nailing which allows early mobilization and weight bearing.

The fracture of fermur is treated by different method e.g plating of femoral shaft fracture is not a good method because patient has to be non weight bearing for long time k-nail fixation there is always a risk of shortening of the leg or rotational deformity especially in comminuted fractures at the end of treatments. In external fixation for comminuted fractures as pins are going through the soft tissue patient feels pain and stiffness of the knee. Which after few months can give significant knee stiffness and can be bed ridden for a long time especially in polytrauma patient.

In fractures of tibial shaft where fixation is indicated it can be fixed with plating but unfortunately it has been associated with higher complication and strong enough to take the body weight in early phase of healing.

Similarly external fixation will prevent early weight bearing and has associated with delayed healing. However if the fractures are fixed with I.M.I.L nailing this will allow rapid healing early weight bearing and patient 
should be able to perform daily activities in a few days.

In cases of polytrauma there is absolute indication for fixations of long bones tibia and femur should be fixed with I.M interlocking nails, which will allow early recovery of the patient.

This study presents the authors experience in treating open (G-I and G-II) and closed fractures of shaft of femur and tibia with reamed Intramedullary interlocking nails, in Mansoor Orthopedic Hospital and Sandeman Provincial Hospital, Quetta.

\section{MATERIAL \& METHODS}

From November 2001 to December 2005. 15 patients of fracture shaft of femur and 15 patients of fracture shaft of tibia were treated surgically with reamed Intramedullary interlocking nailing at Mansoor Orthopedic Hospital and Sandeman Provincial Hospital Quetta all cases were treated by Hipokrate C-75 (Turkish) nail systems.

Those patients who were admitted by the authors with the fracture of shaft of femur and tibia all options are discussed in detail and if internal fixation is indicated then interlocking nail was recommended. Open fracture of G-I and G-II who came to the hospital less than three hours were also included. In open fractures nailing was done in less than 18 hours.

The open fractures were classified by Gustilo and Anderson classification.

The present series consisted of 15 fractures of shaft of femur in which two were open G-II and 13 were closed femur fractures classified according to winquest and they were 3 of type 0,4 type I 3 of type 2, 3 of type 3 and 2 of type 2.

The ages of the patient at the time of injury was from 17 years to 70 years with an average of 33 years. The right femur was involved in 9 cases and the left was involved in other all the injuries had been caused by road traffic accident or falls 7 patient had multiple injuries.

\begin{tabular}{|l|c|}
\hline \multicolumn{2}{|c|}{ Associated injuries in factures shaft of femur } \\
\hline Associated Injuries & No of patients \\
\hline Head & 1 \\
\hline Upper limb & 1 \\
\hline Upper limb & 1 \\
\hline Contra lateral lower limb & 2 \\
\hline Ipsilateral lower limb & 3 \\
\hline
\end{tabular}

In our series of 15 fracture shaft of Tibia 4 were open (one type I and three type II) and 11 were closed fractures. There were 2 proximal fracture shaft of Tibia, 9 involving the middle $1 / 3$ and 4 were of distal $1 / 3$ of the shaft. In cases of closed fractures a significant attention was also given to the skin contusions and Tscherny classification was used to grade the severity. They were 3 of grade 0,5 of grade I and 3 grade II. The associated injuries are as shown in the table.

Associated injuries in fracture Shaft of Tibia

\begin{tabular}{|l|c|}
\hline \multicolumn{1}{|c|}{ Associated injuries } & No of patients \\
\hline $\begin{array}{l}\text { Ipsilateral lower limb- fracture femur } \\
\text { (Floating Knee) }\end{array}$ & 2 \\
\hline $\begin{array}{l}\text { Contra lateral lower limb fracture tibia (1) } \\
\text { \& Femur (1) }\end{array}$ & 2 \\
\hline
\end{tabular}

The age of the patients at the time of the injury ranged from 17-70 years with an average of 35 years. The right Tibia was involved in 9 cases and the left was involved in others. Four patients had multiple injuries.

Patient was resuscitated in emergency room for systemic stabilization. In case of open fractures irrigation with minimum of 2 liters of saline and debridement was performed. The patient's tetanus immunization status determined and appropriate treatment was given in case 
of open fractures parenteral antibiotics were given immediately (Cefuroxime for grade I and an Aminoglycoside + Cefuroxime on grade II). Temporary immobilization with skin traction in case of fracture Femur and a back slab in case of fracture Tibia was provided.

\section{OPERATIVE TECHNIQUE}

For the Femoral nails, fractures were reduced on orthopedic table under image intenstifier with the patient placed in supine position. The portal of entry was located medial to the tip of grater trouchenter. The bone was reamed with the flexible reamers to get adequate sized nail. Six Femurs were proximally and distally (by using the option of oval slot in proximal HIPKRATE C -75 Nail system). Distal locking was done with free-hand technique.

In case of tibial nails the fractures were reduced on orthopedic table under image intensifier while the patient was placed in supine position. The Knee was flexed to $90^{\circ}$ and the foot was held with adhesive tape instead of Calcaneal pin. The entry point was taken in the middle of the bone above the Tibia tuberosity either through the ligamentum patellae (0) from the side. The bone was reamed with a flexilble reamer to get adequate sized Nail except in two cases, which did not, requires any reaming at al. the distal locking was done with a free hand technique.

Parentarel Antibiotics were started immediately (Cefuroxime) for open fractures for three days. And then on oral antibiotics for three weeks. Regarding closed fractures prophylactic antibiotic Cefuroxime $1.5 \mathrm{gm}$ was given at the time of indication and then $1.5 \mathrm{gm}$ TDS for 48 hours. Five days course of oral antibiotics was also given.

The passive mobilization of Knee joint in case of Femoral nail and of Ankle joint in case of Tibial nail was started from $1^{\text {st }}$ post op day. Patients were mobilized with nonweight bearing crutches on $3^{\text {rd }}$ post op. day and were discharged home on nailing $5^{\text {th }}$ day in case of isolated fractures. Immediate nailing in 24 hours time was done in most of the cases except three Tibial fractures. This was delayed from 2-9 days (on average 5 days) because of significant contusion swelling.
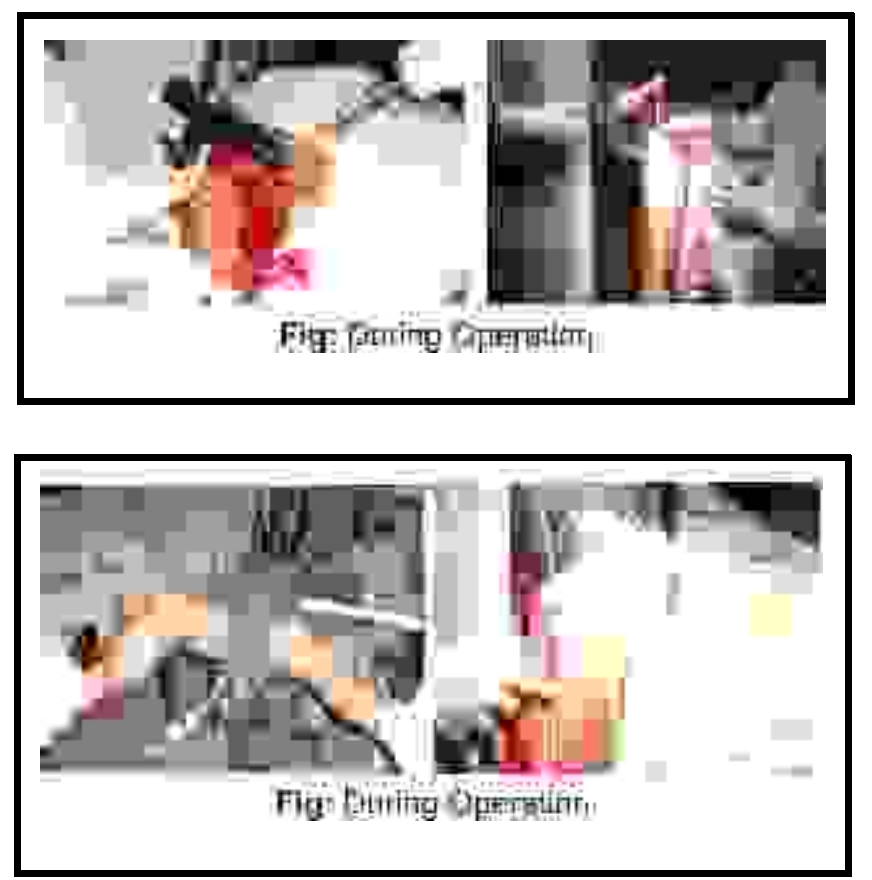

\section{RESULTS}

In case of femoral fractures the patients were hospitalized for isolated fractures Femur for an average of 7 days (range: 6-9 days). However in case of poly trauma the average stay was 20 days (rage: $10-45$ days). Patient were permitted early ambulation with crutches and partial weight bearing was allowed at an average of 12 weeks (range: immediately to 10 week). Full weight bearing was started after an average of 5 weeks (range: immediately to 10 week). Full weight bearing was allowed at an average of 12 weeks (range: 6-24 weeks). Weight bearing was delayed in patients with every proximal or distal fractures as well as in poly trauma patients. None of the patients developed deep infection and neurological complications. Pulmonary embolism developed in one patient three days after operative stabilization: 18 years old man with multiple injuries. This patient required 
ventilatory support for 18 days.

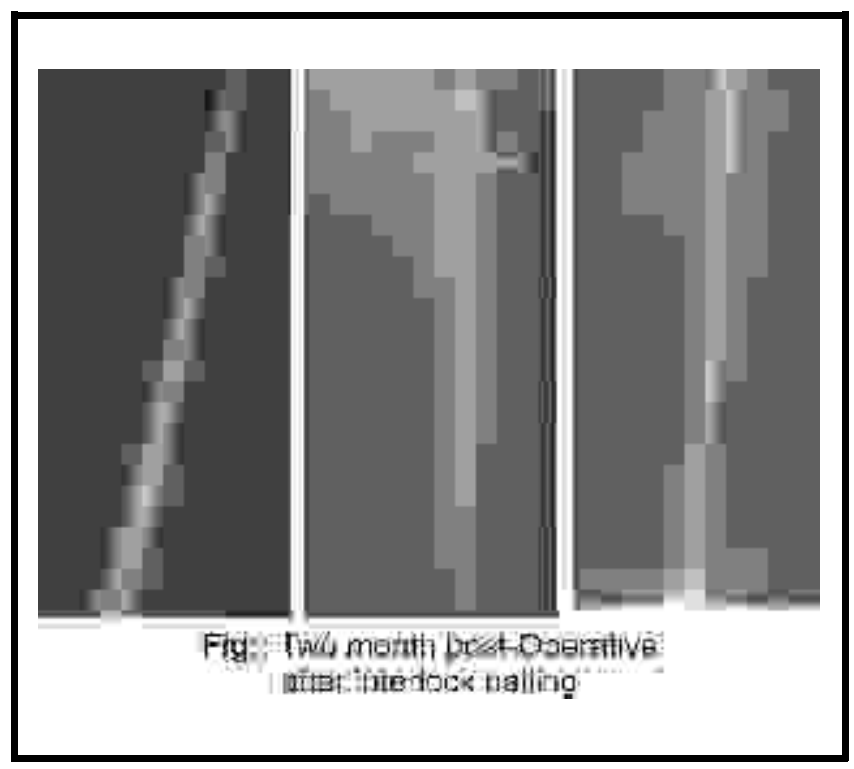

In one case the nail broken at the level of superior distal locking hole at 8 months from the day of nailing. In this case the fracture was very distal (Winquest type III) and there was no room for second locking screw.

Non of the patient developed any significant rotational deformity, however one patient did develop distraction of $1 \mathrm{~cm}$ at the fracture site and waiting for dyanamization. One patient who was initially treated with External Fixator for floating knee and contralateral Tibial fracture later on had nailing of the floating knee has range of movement of Right knee from $0^{\circ}-70^{\circ}$ at 3 month post op although he is full weight bearing.

In case of fracture shaft of Tibia, patients were hospitalized for an average 6 day (5-9 days) and poly trauma cases an avg. of 19 days (12-25 days). Passive mobilization of the knee and the Ankle joint was started immediately in the post op. period. Patient was permitted early mobilization with crutches. Partial weight bearing was started after an avg: of 4 week (range: 4 days 10 weeks) and full weight bearing without crutches aid was allowed at an avg. of 12 weeks (6-20 weeks). Weight bearing was delayed in segement fractures and Polly trauma patients. Dyanamization was done in four cases on average at 6 months (4-8 months).
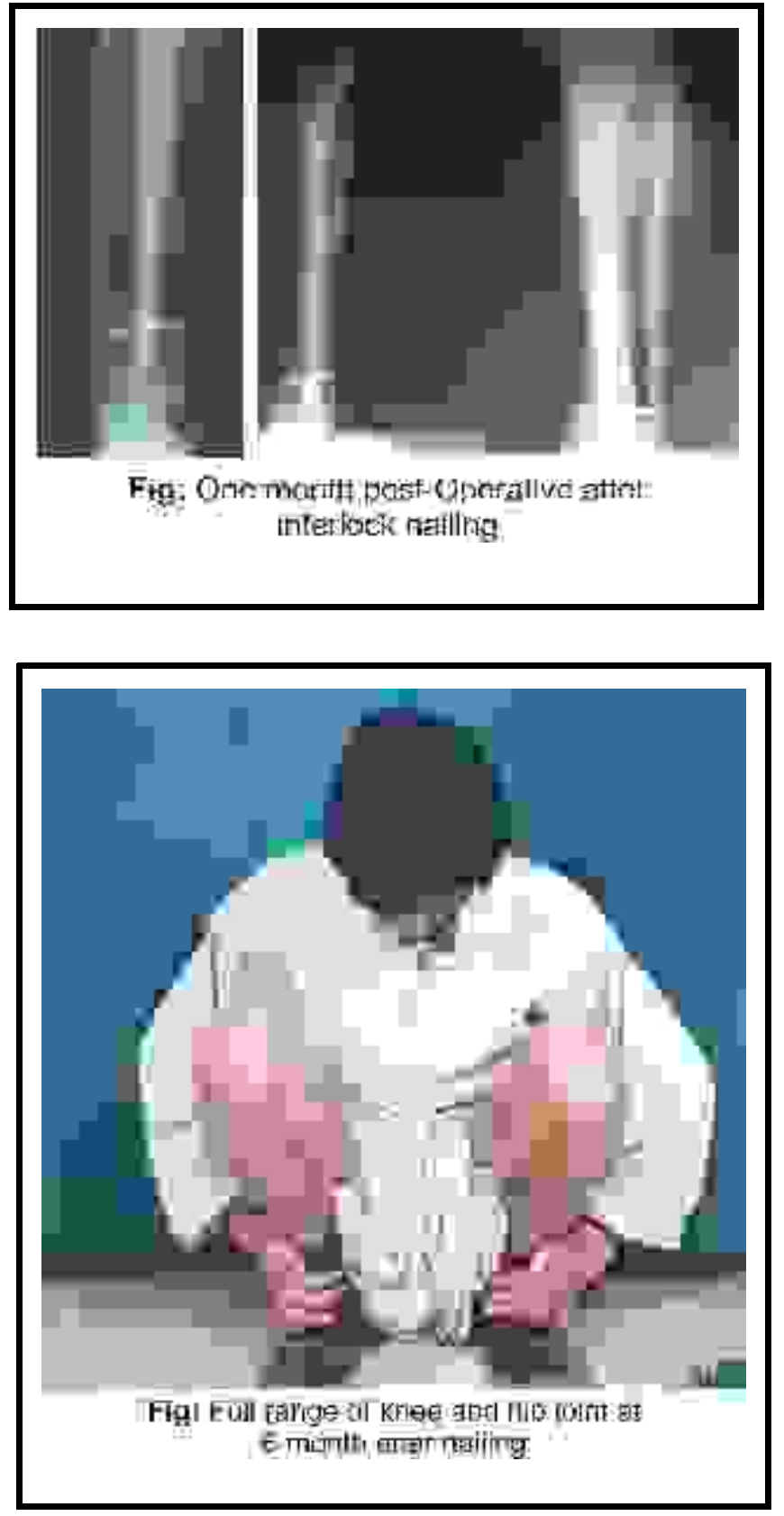


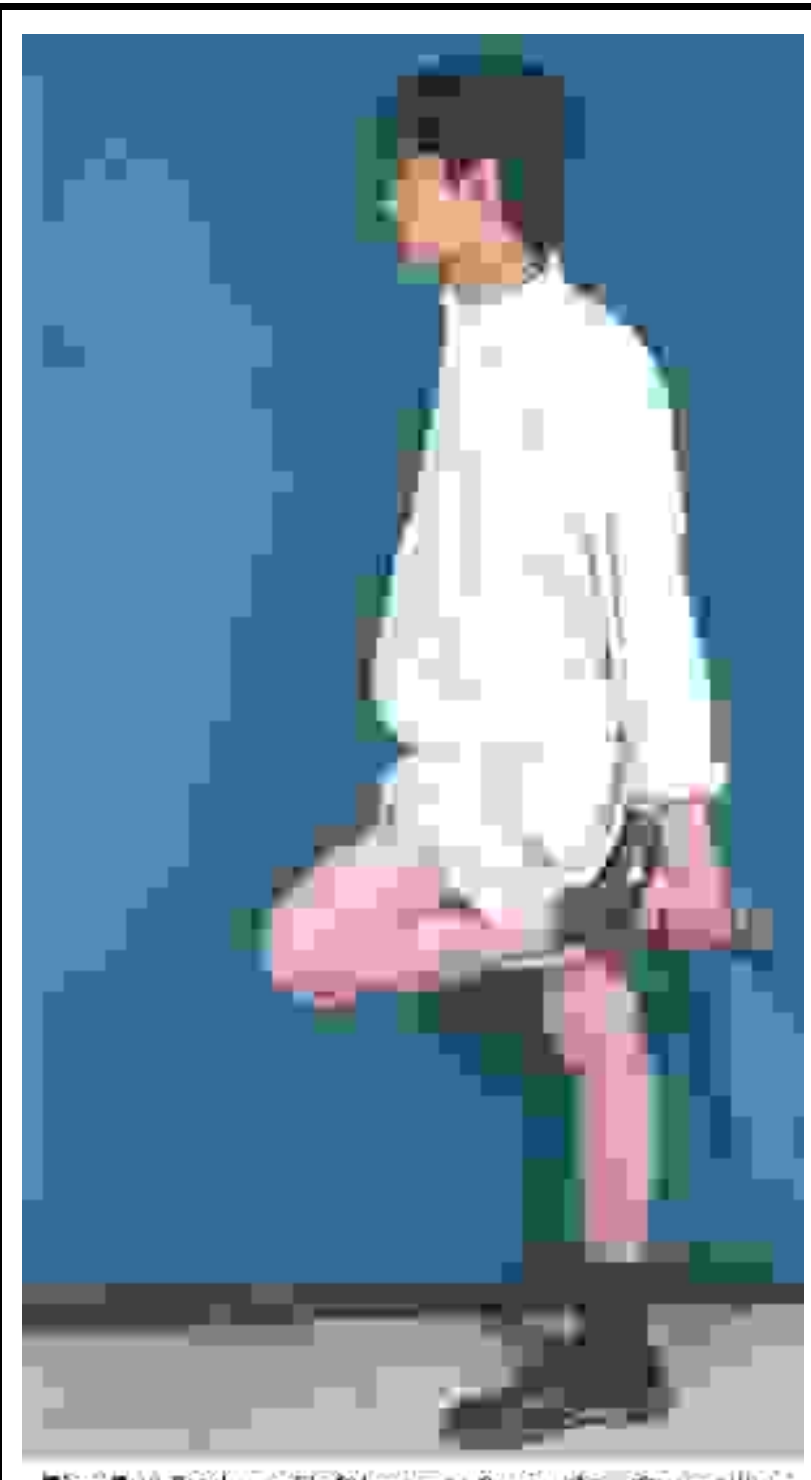

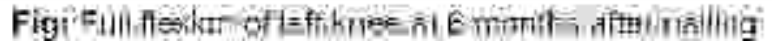

No patient developed wound infection although in one case there was slight necrosis of skin border of the wound which healed on its own over a period of three weeks. This was a case of poly trauma and patient was run over by a bus. He had open contralateral facture that was immediately nailed.
His Tibia was a segmental fracture with significant contusion a segmental fracture with significant contusion especially around the knee (Tscherny type II) and delayed nailing was done. No patient had neurological complication. Pulmonary embolism developed in one patient on third day after the nailing and required ventilatory support for 18 days (same patient as mention above). All patient had nearly all movements of the knee and ankle joints except two patients. One patient was of the above mentioned segmental fracture and second patient is the one with ipsilateral Tibia and Femoral fracture and was initially treated with external fixator and delayed nailing was done at four weeks.

\section{DISCUSSION}

We have shown that intramedullary-interlocking nailing is a good technique for the fracture shaft of femur and tibia for all displaced closed and open fractures up to grade II. Although our series is relatively small at the moment but it is still very encouraging. We have $0 \%$ infection rate and no significant metal failure.

The major advantage of the technique appears to lie in the increased mobility. Patient do not require a cast even in Tibial factures. Over $90 \%$ of the patient were weight bearing by six weeks. The increased mobility provided by the closed nailing facilities return to the full activity. It is very fundamental to have an image intensifier to do closed interlocking intramedullary nailing. Unfortunately it is available only in very few centers. This is the real dilemma and one can not perform the modern trauma management without this vital equipment. The price of the nail is relatively high as compared to the external fixator and plates but this definitely provide more advantage and benefits for quick recovery of patients and definitely is cost effective.

In case of poly trauma and ipsilateral fractures some time for the closed tibial fractures, K-nailing can be used, if there is no need of locking as we did in one of our cases. External fixator is not a good option for the fracture Femur and even in fracture Tibia has been associated 
with more delayed union and mal union.

\section{CONCLUSION}

We believe that interlocking intramedullary nailing of closed as well as grade I and grade II open fracture is a safe technique even in our setup. It provides a high rate of union less complications and early return to function.

\section{REFERENCE}

1. Alho, A., Ekeland A. Stromsoe, K., folleras G., Thoresen, B.O: Locked Intramedually Nailing for Displaced Tibial Shaft Fractures., J. bone Joint Br. Vol. 72-B, 5, Sep. 1990, pp 805-809.

2. Baixauli F. Sr. MD., Sanchez-Alepauz E., Baixauli F. Jr. $M D$ : Intrameduallary interlocking nailing for treatment of open Femoral shaft fractures Clinical orthopedics No: 350 pp. 67-73 1988.

3. Behrens, F., Searis K. External fixation of the tibia Basic concepts and prospective evaluation.; J Bone Joint Br. Vol. 68-B, NO. 2, March 1986 pp. 246-254.

4. Court Brow, C.M., Keating J. F McQueen M. M.: infection after intrameduallary nailing of Tibia Incidence and protocol for management; J. Bone Joint $\mathrm{Br}$. Vopl. 74-B No. 5 Sep 1992. pp. $770-774$.

5. Chapman MW. The role of Intrameduallry fixation in open fractures. Clin Orthop. 1986 212; 2616-34.

6. Court Brown CM, Christic J. McQueen MM, Closed intrameduallry Tibial nailing. Its use in closed and type I open fracture J. Bone Joint Surgery (Br) 1990 a 72-B:
605-11.

7. Gross, A., Christie J., Taglarg G. Court Brown C., Mc Queen MM. Open adult Femoral fractures treated by intramedullary interlocking nailing J. Bone Joint $\mathrm{Br}$. Vol 75-B No: 4 July 1993, pp. 562-565.

8. Gestilo RB, Anderson JT. Prevention, of infection in the treatment of One Thousand and twenty five open fracture of long bones; per-operative and preoperative analysis. J. Bone J. Surgery (Am) 1976 58-A: 453-8.

9. Interlocking intramedullary nailing in femoral shaft fractures. A report of fourty-eight cases. J. Bone Joint Surgery (Am) 1985; 67-A, 1313-20.

10. Oestern H.J Tscherne H. Pathophysiology and classification of soft tissue injuries associated with fractures. Berlin, etc Springer-Vertag 1984: 1-9.

11. Robinson C.M, Mc-Laurance G. J. Mclean I., Court Brown C.; Distal metaphyseal fractures of the Tibia with minimal involvement of Ankle; Classification and treatment by intrameduallry interlocking nailing. J. Bone Joint Br Vol. 77-B No: 5 Sep: 1995 pp. 781-787.

12. Sojbreg, J.V., Eiskaer S., Motler-Larsen F. Locked nailing of comminuted and unstable fractures of Femus. J. Bone Joint Br. Vol.: 72-B No. 1 Jan. 1990 pp. 23-25.

13. Thakaur, A.J., Patankar J.: Open Tibial fractures Treatment by unipolar external fixation and early bone grafting.; J. bone Joint Br. Vol. 73-B NO. 3, May 1991, pp. 448-451. 